\title{
BRIKET BIOMASSA DARI JERAMI PADI, SAMPAH DAUN DAN KOTORAN SAPI
}

\author{
Retno Ambarwati Sigit Lestari \\ Jurusan Teknik Kimia, Fakultas Teknik, Universitas 17 Agustus 1945 Semarang \\ Jl. Pawiyatan Luhur, Bendan Dhuwur Semarang. \\ "Email: retnotengaean@gmail.com
}

\begin{abstract}
Abstrak
Indonesia memiliki banyak limbah pertanian yang selama ini hanya dibiarkan atau dibakar begitu saja. Limbah pertanian yang merupakan biomassa mengandung selulosa cukup tinggi dapat digunakan sebagai sumber energi terbarukan berupa briket. Penelitian ini bertujuan untuk mengetahui karakteristik briket yang dibuat dari jerami padi, sampah daun dan kotoran sapi untuk dibandingkan dengan standar briket arang. Dalam penelitian ini dibuat briket dari bahan jerami padi, sampah daun dan kotoran sapi. Pembuatan briket biomassa dilakukan dengan teknik karbonisasi di dalam drum yang tertutup. Arang yang diperolah dihaluskan dan diayak 50 mesh selanjutnya ditambah bahan perekat berupa tapioka dengan perbandingan 7:1 dan sedikit air kemudian dicetak secara manual. Setelah dicetak, briket arang yang diperoleh dijemur dibawah sinar matahari selama 3 hari. Waktu terbentuknya arang dari berbagai jenis biomassa berbeda-beda, waktu optimum untuk bahan dari jerami padi 30 menit, sampah daun 60 menit dan 75 menit untuk kotoran sapi dengan rendemen masing-masing 24,39\%, 29,03\%, dan 26,26\%. Briket yang dihasilkan dari biomassa jerami padi memiliki kadar air 5,9\% kadar abu 8,02\%, kadar zat mudah menguap 35,68\%, kadar karbon terikat 37,48\% dan nilai kalor $3000 \mathrm{kal} / \mathrm{gr}$. Briket dari sampah daun memiliki kadar air 5,6\%, kadar abu 8,02\%, kadar zat mudah menguap 32,46\%, kadar karbon terikat 40,55\% dan nilai kalor 4600 kal/gr. Briket dari kotoran sapi memiliki kadar air 8,4\%, kadar abu 8,32\%, kadar zat mudah menguap 26,63\%, kadar karbon terikat 50,66\% dan nilai kalor $5200 \mathrm{kal} / \mathrm{gr}$.
\end{abstract}

Kata kunci: briket, jerami padi, kotoran sapi,nilai kalor, sampah daun.

\begin{abstract}
Indonesia has a lot of agricultural waste that has been left or burned. Agricultural waste containing high cellulose which to be used as a renewable energy source in the form of briquettes. This study aims to find out the characteristics of briquettes made from rice straw, leaf litter and cow dung to be compared to standard charcoal briquettes. In this study made briquettes from rice straw, leaf waste and cow dung. The manufacture of biomass briquettes was done by carbonization in a closed drum. The charcoal reduced in size in 50 mesh added tapioca adhesive in ratio of 7: 1 and a little water then formed to be briquettes manually. The charcoal briquettes obtained are dried in the sun for 3 days. The time for formation of charcoal from various types of biomass were varies, the optimum time for rice straw was 30 minutes, leaf waste was 60 minutes and 75 minutes for cow dung with yields of charcoal of rice straw was $24.39 \%, 29.03 \%$ for leaf waste and cow dung was $26.26 \%$. Briquettes produced from biomass of rice straw have a water content of $5.9 \%$ ash content of $8.02 \%$, a volatile substance content of $35.68 \%$, a carbon-bound content of $37.48 \%$ and a heat value of $3000 \mathrm{cal} / \mathrm{gr}$. Briquettes from leaf litter have a water content of $5.6 \%$, ash content of $8.02 \%$, a volatile substance content of $32.46 \%$, a carbon-bound content of $40.55 \%$ and a heat value of 4600 cal/gr. Briquettes from cow dung have a water content of $8.4 \%$, ash content of $8.32 \%$, a volatile substance content of $26.63 \%$, a carbon-bound content of $50.66 \%$ and a heat value of $5200 \mathrm{cal} / \mathrm{gr}$.
\end{abstract}

Keywords: briquettes, cow dung, heat value, leaf litter rice straw..

\section{PENDAHULUAN}

Sampai saat ini Indonesia masih mengandalkan sumber energi yang berasal dari hasil penambangan untuk memenuhi kebutuhan. Energi fosil yang berupa minyak, gas, dan batubara merupakan sumber energi yang tidak dapat diperbaharui. Sementara itu, semakin lama laju kebutuhan bahan bakar negara kita semakin meningkat, seiring dengan meningkatnya pertumbuhan ekonomi dan pertumbuhan jumlah penduduk yang pesat. Energi biomassa merupakan sumber energi yang penting untuk kelangsungan hidup manusia (Wang dkk., 2018). Konsumsi sumber energi jenis ini menempati urutan keempat di dunia setelah batubara, minyak, dan gas alam 
dan menempati posisi vital dalam seluruh sistem energi (Huang dkk., 2020).

Indonesia memiliki banyak limbah pertanian yang selama ini sebagian besar hanya dibiarkan atau dibakar begitu saja. Hal seperti ini tidak hanya menyebabkan pemborosan energi biomassa, tetapi juga meningkatkan pencemaran lingkungan. Limbah pertanian yang merupakan bahan biomassa yang mengandung selulosa ini sebenarnya dapat digunakan sebagai sumber energi terbarukan (Manisha \& Yadav, 2017). Pemanfaatan limbah biomassa yang mengandung selulosa tidak hanya menghasilkan sumber energi alternatif, tetapi juga mengurangi masalah pencemaran lingkungan. Energi biomassa saat ini sumbernya melimpah, merupakan sumber energi terbarukan, dan ramah lingkungan, sehingga memiliki prospek untuk dikembangkan (Sakkampang \& Wongwuttanasatian, 2014).

Penelitian ini bertujuan untuk mengetahui pengaruh kadar air biomassa dan waktu pirolisis terhadap rendemen bioarang yang dihasilkan. Penelitian ini juga ingin mengetahui karakteristik briket yang dibuat dari jerami padi, sampah daun dan kotoran sapi untuk dibandingkan dengan standar briket arang dari beberapa negara, serta untuk mengetahui sifatnya saat digunakan sebagai bahan bakar.

Limbah bio-massa dapat dipadatkan untuk menyiapkan biofuel padat, yang merupakan salah satu cara utama pemanfaatan bioenergi (Xiao dkk., 2015). Briket biomassa semakin difokuskan di bidang biofuel karena lebih praktis dalam pengangkutan maupun penyimpanan (Song dkk., 2014).

Teknik karbonisasi biomassa memiliki keuntungan diantaranya kebutuhan bahan baku yang rendah, dengan alat dan proses sederhana, dan konsumsi energi rendah (Hu dkk., 2018). Dibandingkan dengan biomassa asli, arang biomassa menunjukkan keunggulan yang signifikan, tidak hanya dalam kepadatan, penyimpanan dan transportasi yang mudah tetapi juga dalam penggunaannya (Riva dkk., 2019).

Dibandingkan dengan batubara, biomassa menghasilkan lebih sedikit abu, nitrogen, belerang dan emisi yang lebih rendah dari polutan pembakaran, yang akan mengurangi emisi $\mathrm{CO}_{2}$. Oleh karena itu, briket dari biomassa ini merupakan bahan bakar alternatif yang lebih baik, mudah terbakar, sifat tanpa asap, non-polusi, kadar abu yang rendah, serta nilai kalor yang tinggi. Berdasar spesifikasi tersebut, bahan bakar briket arang lebih baik daripada arang alam (Demirbas, 2009).

Pembuatan bahan bakar meliputi empat langkah yaitu, karbonisasi bahan baku penghancuran, pengeringan, pembuatan briket high-density dengan hot-press. Karena konsumsi energi pengeringan yang tinggi dan briket hot-press kepadatan tinggi, komponen utama briket rentan aus. Batang bahan bakar sering terdistorsi setelah karbonisasi dan permukaannya mudah retak. Kelemahan ini membatasi promosi industrialisasi dan penerapan teknologi. Oleh karena itu, untuk mengembangkan proses karbonisasi dengan konsumsi energi rendah, biaya rendah, kualitas arang yang lebih baik, briket yang dapat memenuhi persyaratan, memiliki signifikansi yang tinggi (Temmerman dkk., 2006).

Operasi spesifik secara konvensional dengan proses pirolisis adalah untuk menambahkan berbagai biomassa di bawah kondisi anaerobik atau anoksik, yang dipanaskan pada suhu yang sesuai (tergantung pada bahan yang berbeda). Selama proses pirolisis biomassa dibutuhkan panas dan mengeluarkan berbagai senyawa gas serta menghasilkan arang (T. Chen dkk., 2015).

Secara umum, pirolisis lambat dengan suhu rendah bertujuan untuk memaksimalkan produksi arang, dengan hasil berat dan hasil energi masing-masing mencapai $30 \%$ berat dan $50 \%$ (Bridgwater \& Peacocke, 2000). Arang biomassa setelah dibuat briket dapat digunakan sebagai bahan bakar yang bersih, yang secara efektif dapat mengurangi emisi polutan (Sun dkk., 2019).

Rendemen dan nilai kalor arang biomassa berbeda pada suhu yang beragam (Zanzi dkk., 2002). Kloss dkk. (2012) mempelajari karbonisasi jerami padi pada kondisi suhu yang berbeda. Dari hasil penelitian tersebut hasil arang menurun dari $39,4 \%$ berat menjadi $27,8 \%$ berat dari suhu 400 menjadi $900{ }^{\circ} \mathrm{C}$ dan arang yang diperoleh pada suhu $500{ }^{\circ} \mathrm{C}$ memiliki nilai kalor tertinggi sebesar 27,68 $\mathrm{MJ} / \mathrm{kg}$. Dari penelitian tersebut juga menunjukkan bahwa hasil karbon tertinggi adalah $34 \%$ berat dan $36 \%$ berat pada suhu $400{ }^{\circ} \mathrm{C}$. Semakin tinggi suhu, semakin rendah hasil arang itu.

Mutu briket biomassa ditentukan berdasarkan sifat fisik dan kimia, yang meliputi kadar air, kadar abu, kadar zat menguap, nilai kalor, kerapatan dan kuat tekan dengan standart 
untuk masing masing negara sebagai berikut seperti pada Tabel 1 (Manisi dkk., 2019).

Tabel 1. Standart Briket Arang Sifat Briket Indones Jepang Inggris Amerika Arang

\begin{tabular}{lllll} 
Arang & & & \\
\hline $\begin{array}{l}\text { Kadar air } \\
(\%)\end{array}$ & 8 & $6-9$ & $3-6$ & 6,2 \\
$\begin{array}{l}\text { Kadar zat } \\
\text { mudah } \\
\text { menguap } \\
(\%)\end{array}$ & 15 & $15-30$ & 16,4 & $19-24$ \\
$\begin{array}{l}\text { Kadar abu } \\
(\%)\end{array}$ & 8 & $3-6$ & 5,9 & 8,3 \\
$\begin{array}{l}\text { Kadar karbo } \\
\text { terikat }\end{array}$ & $60-80$ & 75,3 & 60 \\
$\begin{array}{l}(\%) \\
\text { Kerapatan } \\
\left.\text { (g/cm }{ }^{3}\right)\end{array}$ & - & $1-1,2$ & 0,46 & 1 \\
$\begin{array}{l}\text { Kuat tekan } \\
\left.\text { (kg/cm }{ }^{2}\right)\end{array}$ & - & $60-65$ & 12,7 & 62 \\
$\begin{array}{l}\text { Nilai kalor } \\
(\mathrm{kal} / \mathrm{g})\end{array}$ & 5000 & $6000-$ & 7289 & 6230 \\
\hline
\end{tabular}

\section{METODOLOGI}

Penelitian ini dilakukan dengan menggunakan alat karbonisasi berupa drum 200 liter. Biomassa yang berupa limbah tanaman maupun kotoran hewan yaitu jerami padi, sampah daun, kotoran sapi (masing masing diproses sendiri) dengan jumlah tertentu dan kadar air tertentu dimasukkan dalam drum lalu dibakar. Pada saat proses pembakaran, permukaan/mulut drum ditutup/disempitkan. Hal ini dilakukan untuk mengurangi masuknya oksigen ke dalam drum, sehingga api tidak menyala dan hanya mengeluarkan kepulan asap, agar sampah menjadi arang dengan sempurna. Setelah proses pembakaran mencapai waktu tertentu, pembakaran dihentikan dengan cara menyiramkan sedikit air ke dalam sampah yang dibakar. Hasil pembakaran didiamkan sebentar dan arang yang diperolah dikeluarkan dari drum dan dihaluskan dan diayak 50 mesh

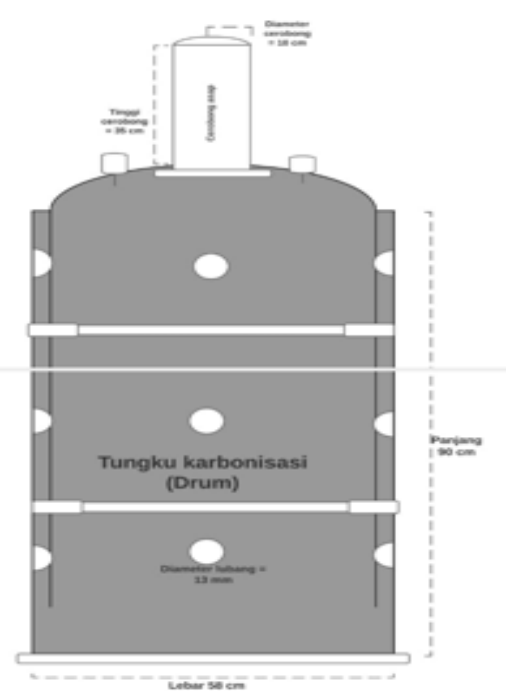

Gambar 1. Alat Karbonisasi Biomassa

Selanjutnya arang yang telah dihaluskan ditambah bahan perekat berupa tapioka dengan perbandingan 7:1 dan sedikit air kemudian dicetak secara manual. Setelah dicetak, briket arang yang diperoleh dijemur dibawah sinar matahari selama 3 hari. Analisis kadar air briket dilakukan dengan thermogravimetri, sedangkan rendemen dihitung berdasarkan berat arang yang diperoleh dibagi berat bahan baku mula mula dikalikan $100 \%$.

\section{HASIL DAN PEMBAHASAN}

\subsection{Pengaruh Kadar Air Biomassa terhadap Rendemen}

Dari penelitian pembuatan briket dari bahan jerami padi, sampah daun, dan kotoran sapi diperoleh hasil seperti dalam Tabel 2.

Table 2. Perbandingan Bioarang dari berbagai jenis biomassa

\begin{tabular}{|c|c|c|c|c|}
\hline $\begin{array}{c}\text { Jenis } \\
\text { Biomassa }\end{array}$ & $\begin{array}{l}\text { Kadar } \\
\text { Air } \\
(\boldsymbol{\%})\end{array}$ & $\begin{array}{l}\text { Waktu } \\
(\mathbf{m e n i t})\end{array}$ & $\begin{array}{l}\text { Suhu } \\
\left({ }^{\circ} \mathbf{C}\right)\end{array}$ & $\begin{array}{l}\text { Rendemen } \\
(\boldsymbol{\%})\end{array}$ \\
\hline Jerami & 10,64 & 15 & 250 & 19,43 \\
padi & & 30 & 283 & 24,39 \\
& & 45 & 296 & 22,33 \\
\hline & 14,7 & 15 & 243 & 17,44 \\
& & 30 & 254 & 20,19 \\
& & 45 & 270 & 22,45 \\
\hline & 19,8 & 15 & 235 & 15,31 \\
& & 30 & 244 & 17,29 \\
& & 45 & 268 & 22,13 \\
\hline Sampah & 9,6 & 30 & 288 & 22,54 \\
daun & & 45 & 293 & 25,43 \\
& & 60 & 295 & 29,03 \\
& & 75 & 298 & 28,14 \\
\hline & 15,3 & 30 & 268 & 17,44 \\
& & 45 & 289 & 20,31 \\
& & 60 & 295 & 24,62 \\
\hline
\end{tabular}




\begin{tabular}{|c|c|c|c|c|}
\hline & & 75 & 298 & 29,02 \\
\hline & 19,9 & 30 & 233 & 14,02 \\
& & 45 & 256 & 16,33 \\
& & 60 & 278 & 18,39 \\
& & 75 & 282 & 20,01 \\
\hline Kotoran & 10,4 & 45 & 278 & 18,23 \\
sapi & & 60 & 281 & 21,31 \\
& & 75 & 295 & 25,26 \\
& & 90 & 299 & 24,45 \\
\hline & 15,7 & 45 & 241 & 13,13 \\
& & 60 & 262 & 15,38 \\
& & 75 & 275 & 18,01 \\
& & 90 & 288 & 23,33 \\
\hline & 19,8 & 45 & 229 & 11,45 \\
& & 60 & 246 & 13,23 \\
& & 75 & 257 & 15,46 \\
& & 90 & 281 & 17,46 \\
\hline
\end{tabular}

Briket Jerami Padi

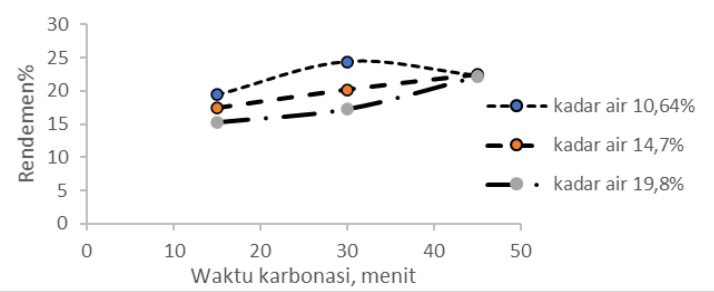

Gambar 2. Grafik hubungan waktu karbonisasi jerami padi dengan rendemen

Dari Tabel 2, Gambar 2, Gambar 3, dan Gambar 4, tampak bahwa semakin tinggi kadar air biomassa yang dibuat menjadi briket, diperoleh rendemen bioarang yang lebih rendah. Hal ini dikarenakan semakin tinggi kadar air pada biomassa, maka panas dari proses pembakaran tersebut dipergunakan untuk menguapkan air biomassa terlebih dahulu, sehingga suhu yang dicapai pada waktu yang sama masih rendah dan biomassa belum membentuk arang.

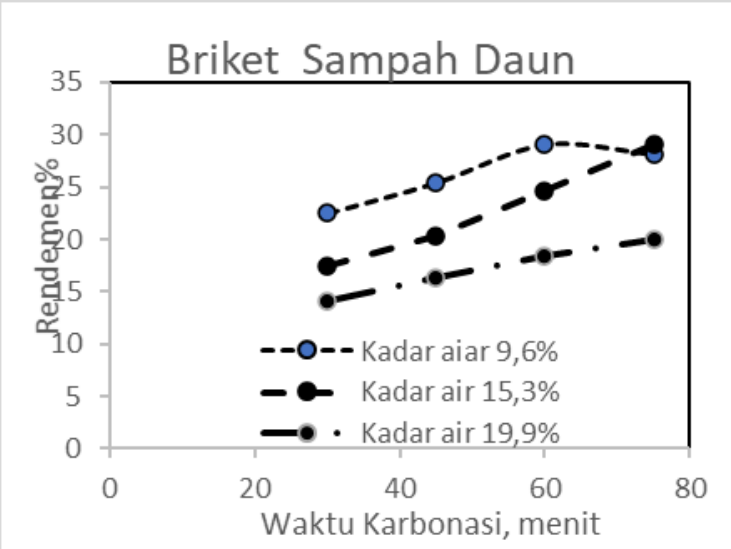

Gambar 3. Grafik hubungan waktu karbonisasi sampah daun dengan rendemen
Berdasarkan data yang ada juga nampak bahwa semakin lama waktu proses pembakaran diperoleh rendemen yang semakin besar karena dengan bertambahnya waktu maka proses pembentukan arang semakin optimal, tetapi apabila waktu diperpanjang maka rendemen yang diperoleh akan turun karena arang yang terbentuk akan menjadi abu. Waktu optimum untuk memperoleh briket bioarang untuk bahan jerami padi adalah 30 menit, pada kadar air bahan $10,6 \%$ dan diperoleh rendemen arang sebesar 24,3\%. Sedangkan briket dari sampah daun dengan kadar air bahan 9,6\% diperoleh rendemen sebesar $29,03 \%$. Untuk arang dari kotoran sapi diperoleh rendemen sebesar $25,26 \%$ pada waktu optimum 75 menit dan kadar air bahan $10,4 \%$. Bila dibandingkan dengan hasil penelitian Karaosmanoglu dkk. (2000), dari hasil pirolisis jerami padi memberikan yiel bioarang antara $27,11 \%$ $28,23 \%$. Hasil tersebut hampir sama dengan hasil penelitian ini.

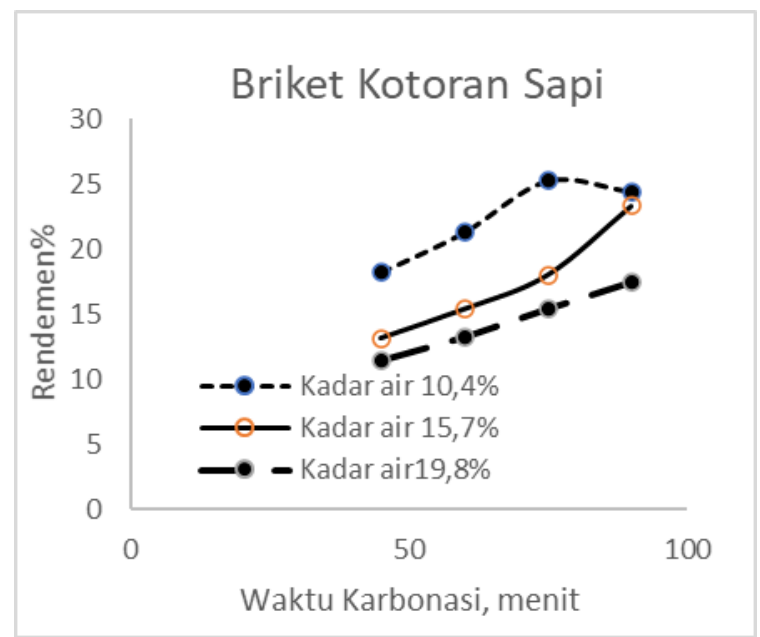

Gambar 4. Grafik hubungan waktu karbonisasi kotoran sapi dengan rendemen

Dari data hasil penelitian di atas nampak bahwa waktu yang diperlukan oleh biomassa dari jerami padi untuk memperoleh rendemen yang optimum lebih singkat dibanding dari sampah daun maupun dari kotoran sapi. Demikian juga waktu yang diperlukan oleh sampah untuk menjadi arang lebih singkat dibanding dari bahan kotoran sapi. Hal ini dikarenakan masing-masing bahan tersebut memiliki suhu karbonisasi yang berbeda, dan jerami memiliki suhu karbonisasi paling rendah dibanding sampah daun dan kotoran sapi. 
3.2. Karakteristik Briket Jerami Padi, Sampah Daun, dan Kotoran Sapi

Dari briket bioarang yang diperoleh dari ketiga jenis bahan tersebut, selanjutnya diuji kadar air, kadar abu, kadar zat mudah menguap, kadar karbon terikat dan nilai kalor.

Tabel 3. Kadar Air dan Kadar Abu Briket dari Biomassa

\begin{tabular}{lcc}
\hline Jenis Briket & $\begin{array}{c}\text { Kadar Air } \\
(\mathbf{\%})\end{array}$ & $\begin{array}{c}\text { Kadar Abu } \\
(\mathbf{\%})\end{array}$ \\
\hline Jerami padi & 5,9 & 8,02 \\
Sampah daun & 5,6 & 8,13 \\
Kotoran sapi & 8,4 & 8,32
\end{tabular}

Berdasarkan nilai kadar air dari ke tiga briket biomassa tersebut semua memenuhi standart yang ditetapkan Indonesia dan Jepang. Sedangkan untuk kadar abu mendekati yang ditetapkan oleh standart nasional (Manisi dkk., 2019).

Untuk nilai kadar zat mudah menguap serta kadar karbon terikat dari ke tiga briket biomassa tersebut dihasilkan seperti pada Tabel 4.

Tabel 4. Kadar Zat Mudah Menguap dan Kadar Karbon Terikat Briket dari Biomassa

\begin{tabular}{|lll|}
\hline Jenis Briket & $\begin{array}{l}\text { Kadar zat } \\
\text { mudah } \\
\text { menguap } \\
(\boldsymbol{\%})\end{array}$ & $\begin{array}{l}\text { Kadar karbon } \\
\text { Terikat }(\%)\end{array}$ \\
\hline Jerami padi & 35,68 & 37,48 \\
Sampah daun & 32,46 & 40,55 \\
Kotoran sapi & 26,63 & 50,66 \\
\hline
\end{tabular}

Berdasar Tabel 4 nampak bahwa kadar zat mudah menguap briket dari ketiga biomassa tersebut tidak memenuhi standart (Manisi dkk., 2019).

Untuk nilai kalor dari briket biomassa dari hasil penelitian ini diperoleh hasil seperti pada Tabel 5.

\begin{tabular}{llll}
\multicolumn{3}{c}{ Tabel 5. Nilai Kalor } & Briket dari Biomassa \\
\hline $\begin{array}{l}\text { Jenis } \\
\text { Briket }\end{array}$ & $\begin{array}{l}\text { Nilai } \\
\text { Kalor } \\
\text { Bahan } \\
\text { (Kal/gr) }\end{array}$ & $\begin{array}{l}\text { Nilai } \\
\text { Kalor } \\
\text { Briket } \\
(\text { Kal/gr) }\end{array}$ & $\begin{array}{l}\text { Prosen } \\
\text { Kenaikan } \\
\text { Nilai Kalor } \\
(\%)\end{array}$ \\
\hline $\begin{array}{l}\text { Jerami } \\
\text { padi }\end{array}$ & 1600 & 3000 & $87,5 \%$ \\
$\begin{array}{l}\text { Sampah } \\
\text { daun }\end{array}$ & 3000 & 4600 & $53,3 \%$ \\
$\begin{array}{l}\text { Kotoran } \\
\text { sapi }\end{array}$ & 3500 & 5200 & $51 \%$ \\
\hline
\end{tabular}

Dari Tabel 5 menunjukkan bahwa nilai kalor dari briket bioarang lebih tinggi dibandingkan nilai kalor dari biomassa masingmasing. Hal ini dikarenakan dengan proses karbonisasi mampu menaikkan kadar karbon dalam briket bioarang, sehingga akan menaikkan nilai kalornya. Dari pembuatan briket bioarang dari biomassa tersebut dapat menaikkan nilai kalor antara $51 \%-87,5 \%$.

Nilai kalor briket dari kotoran sapi sebesar $5200 \mathrm{kal} / \mathrm{gr}$, nilai ini memenuhi standart nasional. Sedangkan nilai kalor briket sampah daun besarnya $4600 \mathrm{kal} / \mathrm{gr}$, dan briket jerami padi mempunyai nilai kalor sebesar $3000 \mathrm{kal} / \mathrm{gr}$, keduanya tidak memenuhi standart. Bila dibandingkan dengan hasil penelitian yang telah dilakukan oleh Sugiharto dan Lestari (2021), yang membuat briket dari campuran arang sekam padi dan ampas tebu dengan perbandingan tertentu, nilai kalor briket dari hasil penelitian ini nilainya lebih rendah. Hal ini kemungkinan briket yang dihasilkan dalam penelitian ini mengandung abu yang cukup tinggi.

Briket bioarang yang diperolah dari hasil penelitian selanjutnya dilakukan uji coba pembakaran. Dari uji coba tersebut diperoleh data sebagai berikut seperti Tabel 6 .

Tabel 6. Karakteristik Briket saat digunakan

\begin{tabular}{llll}
\hline $\begin{array}{l}\text { Jenis } \\
\text { Biomassa }\end{array}$ & Penyalaan & $\begin{array}{l}\text { Pembentukan } \\
\text { Bara }\end{array}$ & $\begin{array}{l}\text { Pemben- } \\
\text { tukan } \\
\text { Abu }\end{array}$ \\
\hline $\begin{array}{l}\text { Jerami } \\
\text { padi }\end{array}$ & Mudah & Cepat & Cepat \\
$\begin{array}{l}\text { Sampah } \\
\text { daun }\end{array}$ & Mudah & Cepat & Cepat \\
$\begin{array}{l}\text { Kotoran } \\
\text { sapi }\end{array}$ & Agak sulit & $\begin{array}{l}\text { Merambat } \\
\text { perlahan }\end{array}$ & $\begin{array}{l}\text { Bara } \\
\text { tahan } \\
\text { lama }\end{array}$
\end{tabular}

Tabel 7. Karakteristik Briket saat digunakan

\begin{tabular}{llc}
\hline $\begin{array}{l}\text { Jenis Biomassa } \\
\text { Sumber Briket }\end{array}$ & Asap & Bau \\
\hline Jerami padi & Tidak berasap & Tidak berbau \\
Sampah daun & Tidak berasap & Tidak berbau \\
Kotoran sapi & Tidak berasap & Tidak berbau
\end{tabular}

Dari uji coba ternyata briket bioarang dari kotoran sapi lebih sulit menyala dan perambatan bara perlahan-lahan, tetapi bila telah membara, bara yang terbentuk lebih tahan lama dan tidak cepat menjadi abu. 


\section{KESIMPULAN DAN SARAN}

Dari hasil penelitian ini menunjukkan bahwa biomassa yang berasal dari jerami padi, sampah daun dan kotoran sapi dapat dibuat menjadi briket bioarang. Kadar air bahan berpengaruh terhadap proses karbonisasi, semakin tinggi kadar air memerlukan waktu lebih lama untuk pembentukan arang. Waktu terbentuknya arang dari berbagai jenis biomassa berbeda-beda, waktu optimum untuk bahan dari jerami padi 30 menit, sampah daun 60 menit dan 75 menit untuk kotoran sapi dengan rendemen masing-masing $24,39 \% ; 29,03 \%$; dan $26,26 \%$.

Karakteristik briket yang dihasilkan dari penelitian ini: briket jerami padi, briket daun dan briket kotoran sapi memiliki kadar air $5,9 \% ; 5,6 \%$ dan $8,5 \%$ serta kadar abu $8,02 \%$; $8,13 \%$; dan $8,32 \%$. Kadar zat mudah menguap $36,68 \% ; 32,46 \%$ dan $26,63 \%$ dan kadar karbon terikat masing masing sebesar $37,48 \%$; $40,55 \%$; dan $50,66 \%$.

Briket bioarang dari kotoran sapi mempunyai nilai kalor lebih tinggi dibanding dari sampah daun maupun jerami padi, yang masing-masing besarnya $5200 \mathrm{kal} / \mathrm{gr}, 4600$ $\mathrm{kal} / \mathrm{gr}$, dan $3000 \mathrm{kal} / \mathrm{gr}$. Pembentukan briket bioarang dari biomassa dapat meningkatkan nilai kalor bahan hingga $51 \%-87,5 \%$. Briket yang diperoleh dari biomassa tidak berasap dan tidak berbau. Briket bioarang dari kotoran sapi lebih sulit menyala dan perambatan bara perlahan-lahan, tetapi bila telah membara, bara yang terbentuk lebih tahan lama dan tidak cepat menjadi abu.

\section{DAFTAR PUSTAKA}

Bridgwater, A. V., \& Peacocke, G. V. C. (2000). Fast pyrolysis processes for biomass. Renewable and Sustainable Energy Reviews, 4(1), 1-73. https://doi.org/10.1016/S13640321(99)00007-6

Chen, T., Cai, J., \& Liu, R. (2015). Combustion Kinetics of Biochar from Fast Pyrolysis of Pine Sawdust: Isoconversional Analysis. Energy Sources, Part A: Recovery, Utilization and Environmental Effects, $37(20)$, 2208-2217. https://doi.org/10.1080/15567036.2012.68 4737

Chen, Y., Yang, H., Wang, X., Zhang, S., \& Chen, H. (2012). Biomass-based pyrolytic polygeneration system on cotton stalk pyrolysis: Influence of temperature.
Bioresource Technology, 107, 411-418. https://doi.org/10.1016/j.biortech.2011.10. 074

Demirbas, A. (2009). Sustainable charcoal production and charcoal briquetting. Energy Sources, Part A: Recovery, Utilization and Environmental Effects, 31(19), 1694-1699. https://doi.org/10.1080/155670308020940 60

Hu, W., Liang, F., Xiang, H., Zhang, J., Yang, X., Zhang, T., Mi, B., \& Liu, Z. (2018). co-firing characteristics of coal and masson pineInvestigating. Renewable Energy, 126, 563-572. https://doi.org/10.1016/j.renene.2018.03.0 85

Huang, H., Liu, J., Liu, H., Evrendilek, F., \& Buyukada, M. (2020). Pyrolysis of water hyacinth biomass parts: Bioenergy, gas emissions, and by-products using TGFTIR and Py-GC/MS analyses. Energy Conversion and Management, 207(November 2019), 112552. https://doi.org/10.1016/j.enconman.2020.1 12552

Karaosmanoğlu, F., Işigigür-Ergüdenler, A., \& Sever, A. (2000). Biochar from the strawstalk of rapeseed plant. Energy and Fuels, 14(2),

336-339. https://doi.org/10.1021/ef9901138

Manisha, \& Yadav, S. K. (2017). Technological advances and applications of hydrolytic enzymes for valorization of lignocellulosic biomass. Bioresource Technology, 245, 1727-1739. https://doi.org/10.1016/j.biortech.2017.05. 066

Manisi, L., Kadir, \& Kadir, A. (2019). Pengaruh Variasi Komposisi Terhadap Karakteristik Briket Campuran Sekam Padi Dan Kulit Jambu Mete. Jurnal Ilmiah Mahasiswa Teknik Mesin, 4(2), 60-67. http://ojs.uho.ac.id/index.php/ENTHALP $\mathrm{Y}$

Riva, L., Nielsen, H. K., Skreiberg, Ø., Wang, L., Bartocci, P., Barbanera, M., Bidini, G., \& Fantozzi, F. (2019). Analysis of optimal temperature, pressure and binder quantity for the production of biocarbon pellet to be used as a substitute for coke. Applied Energy, 256(September), 113933. https://doi.org/10.1016/j.apenergy.2019.11 3933

Sakkampang, C., \& Wongwuttanasatian, T. 
(2014). Study of ratio of energy consumption and gained energy during briquetting process for glycerin-biomass briquette fuel. Fuel, 115, 186-189. https://doi.org/10.1016/j.fuel.2013.07.023

Song, X., Yu, X., Zhang, M., Pei, Z. J., \& Wang, D. (2014). A physics-based temperature model for ultrasonic vibration-assisted pelleting of cellulosic biomass. Ultrasonics, 54(7), 2042-2049. https://doi.org/10.1016/j.ultras.2014.05.01 5

Sugiharto, A. dan Lestari, I.D. (2021). Briket Campuran Ampas Tebu dan Sekam Padi Menggunakan Karbonisasi secara Konvensional sebagai Energi Alternatif. Inovasi Teknik Kimia, Vol. 6, No. 1, 1-6.

Sun, J., Shen, Z., Zhang, Y., Zhang, Q., Wang, F., Wang, T., Chang, X., Lei, Y., Xu, H., Cao, J., Zhang, N., Liu, S., \& Li, X. (2019). Effects of biomass briquetting and carbonization on PM2.5 emission from residential burning in Guanzhong Plain, China. Fuel, 244(November 2018), 379 387.

https://doi.org/10.1016/j.fuel.2019.02.031

Temmerman, M., Rabier, F., Jensen, P. D., Hartmann, H., \& Böhm, T. (2006). Comparative study of durability test methods for pellets and briquettes. Biomass and Bioenergy, 30(11), 964-972. https://doi.org/10.1016/j.biombioe.2006.0 6.008

Wang, S., Luo, K., Hu, C., Sun, L., \& Fan, J. (2018). Impact of operating parameters on biomass gasification in a fluidized bed reactor: An Eulerian-Lagrangian approach. Powder Technology, 333, 304316.

https://doi.org/10.1016/j.powtec.2018.04.0 27

Xiao, X., Li, C., Ya, P., He, J., He, Y., \& Bi, X. T. (2015). Industrial experiments of biomass briquettes as fuels for bulk curing barns. International Journal of Green Energy, 12(11), 1061-1065. https://doi.org/10.1080/15435075.2014.89 1119

Zanzi, R., Sjöström, K., \& Björnbom, E. (2002). Rapid pyrolysis of agricultural residues at high temperature. Biomass and Bioenergy, 23(5), 357-366. https://doi.org/10.1016/S09619534(02)00061-2 